\title{
METODE LITERASI DALAM PEMBELAJARAN IPS MATERI KERAJAAN-KERAJAAN HINDU-BUDDHA DI INDONESIA PADA SISWA KELAS VIIB SMP KRISTEN SATYA WACANA SALATIGA
}

\author{
Emy Wuryani, Sunardi \\ Email : emy.wuryani@uksw.edu, sunardi.sunardi@uksw.edu \\ Jurusan Sejarah UKSW Salatiga
}

\begin{abstract}
Abstrak
Penelitian ini merupakan jenis penelitian deskripsi tentang Metode Literasi Dalam Pembelajaran IPS. Materi IPS Sejarah di Sekolah Menengah Pertama (SMP) umum nya masih bersifat pemahaman dengan membaca buku teks yang dijadikan pegangan Guru dengan mengacu pada Buku Siswa (BS). Guru belum mampu mengembangkan isi materi sesuai dengan tuntutan Kurikulum 2013. Hal ini mengakibatkan siswa tidak mampu mengembangkan cara berpikirkritis, masihhafalan dan belummampumenagamati dan memahami peristiwa sejarah itu sendiri. Oleh karena itu guru perlu mengembangkan materi dengan bahan litarasi. Penelitian ini bertujuan mendeskripsikan penerapan metode literasi untuk nenanamkan pemahaman sebuah peristiwa sejarah pada mata pelajaran IPS. Metode penelitian adalah deskripsi. Lokasi penelitian di SMP Kristen Satya Wacana Salatiga Kelas VIIB berjumlah 22 siswa. Model pembelajaran yang diterapkan adalah pembelajaran kooperatif dengan menggunakan metode literasi.Teknik pengambilan data dengan testertulis dan pengamatan. Hasil penelitian terbukti bahwa (1) Penerapan model pembelajaran kooperatif dengan metode literasi dapat menanamkan pemahaman sebuah peristiwa sejarah pada siswa dan berpikir kritis. (2) Hasilbelajar IPS pada siswa kelasVIIB SMP Kristen Satya Wacana Salatiga Semester Genap tahun ajaran 2018/2019 semua siswa tuntas dengan nilai tertinggi yang dicapai siswa adalah 100 dan nilai terendah yang dicapai siswa adalah 75 dengan nilai rata-rata kelas 95,5
\end{abstract}

Kata kunci: pembelajaran kooperattif, metode literasi, hasil belajar

\section{Pendahuluan}

Salah satu permasalahan yang di hadapi oleh guru matapelajaran IPS di SMP Kristen Laboratorium Satya Wacana Salatiga dalam proses pembelajaran adalah kurang mengembangkan isimateri IPS Sejarah. Kemampuan guru dalam proses pembelajaran karena keterbatasan sumber bacaan untuk melengkapi isimateri Sejarah. Selama ini guru matapelajaran IPS Sejarah pada saat proses pembelajaran di kelas dalam mengajar belum menggunakanan sumber-sumber lain untuk melengkapi materi sejarah. Selain itu metodepembelajaran yang digunakan guru masih menggunakan pembelajaran konvensional (ceramah), strategi pembelajaran bersifatteacher centered dan kurang melibatkan pesertadidik. Di samping itu, guru 
dalam menyajikan bahan ajar belum menggunakan studi literature sehingga suasana pembelajaran kurangmenarik dan membosankan. Kondisi yang demikian berdampak pada para siswa karena mengalami kesulitan khususnya yang berkaitan dengan nama-nama tokoh, perilaku atau tindakan para tokoh serta keteladanan apa yang dapat dipelajari oleh para siswa. Mengamati fenomena tersebut, penulis menerapkan pembelajarana lternatif untuk kepentingan guru dan siswa. Ini relevan dengan Tucker \& Stronge (2005) yang percaya bahwa guru perlu mengembangkan model pengajaran yang lebih efektif. Dengan demikian, guru harus terampil dalam memilih model yang tepat. Model alternatif yang dikembangkan dalam penelitian ini adalah model storytelling berbasis sugestopedia, di mana setiap siswa harus bekerja dalam kelompok yang dirancang sesuai untuk memastikan bahwa semua siswa berpartisipasi aktif dan efektif dalam pelajaran (Sunardi, dkk. Malaysian Online Journal of Educational Technology Januari2018 (Volume 6 - Issue 1)).

Berdasarkan pengalaman mahasiswa melakukan kegiatan Praktek Pengalaman Lapangan (PPL)di kelas VIIB SMP Kristen Satya Wacana Salatiga, ditemukan permasalahan sebagai berikut: (1) Siswa kurang berminat dalam pembelajaran IPS, (2) siswa kurang aktif, dan beberapa siswa sering mengganggu teman sampingnya, (3) siswa belum mampu memahami peristiwa sejarah, (4) siswa masih mengalami kesulitan untuk berpikirkritis, masih sekedar menghafal teks yang ada. Kesulitan yang dialami siswa terutama ketika diminta menghubungkannya dengan memberikan contoh kenyataan yang ada masa sekarang ini. 5) guru tidak menggunakan media pembelajaran, 6) guru tidak menggunakan metode pembelajaran kooperatif yang dapat membuat pembelajaran menjadi mengasyikkan dan menyenangkan.

Pada pembelajaran IPS di kelas VIIBSMP Kristen Satya Wacana Salatigapada Semester Genap Tahun Ajaran 2018/2019 terdapat materi tentang Kerajaan-Kerajaan Hindu-Buddha dengan sub materi Teori-teori Masuknya Agama Hindu-Buddha di Indonesia yang disajikan dalam bentuk literasi dasar, yakni mengoptimalkan membaca, menulis dan berkomunikasi. Diharapkan melalui literasidasar ini proses pembelajaran menjadi hidup, menarik, dan menyenangkan sehinggasiswa dapat memahamiperistiwa sejarah secara kritis dan ditunjukkan amelalui hasil belajarnya yang baik diatas KKM yang ditetapkan sekolah yakni 70.

Berdasarkan latar belakang masalah diatas maka dapat dirumuskan masalah: Bagaimana menanamkan pemahaman sebuah peristiwa sejarah pada mata pelajaran IPS melalui penerapan literasi pada siswa kelas VIIB SMP Kristen Satya Wacana Salatiga. Adapun tujuan penelitian 201 | Seminar Nasional Sejarah ke 4 Jurusan Pendidikan Sejarah Universitas Negeri Padang 
adalah mendeskripsikan penerapan metode literasi untuk nenanamkan pemahaman sebuah peristiwa sejarah pada mata pelajaran IPS sehingga hasil belajar siswa mencapai ketuntasan belajar yakni 70 .

\section{Kajian Pustaka}

\section{Pembelajaran IPS}

Pelajaran Ilmu Pengetahuan Sosial (IPS) sebagai salah satu mata pelajaran dalam kurikulum 2013 juga berorientasi pada kompetensi yang utuh tersebut. Pelajaran IPS merupakan integrasi dari empat mata pelajaran yaitu geografi, ekonomi, sosiologi dan sejarah. Keempat mata pelajaran tersebut dipadukan oleh konsep ruang dan interaksi antar ruang serta pengaruhnya terhadap kehidupan manusia dalam aspek ekonomi, sosial, budaya dan Pendidikan (Iwan Setiawan, dkk. 2017: iii). Mengacu pada Kurikulum 2013 yang mencirikan penilaian siswa diukur dari 3 bidang, yakni (1) kognitif, berhubungan dengan kemampuan intelektual atau kemmapuan berpikir (mengingat dan memecahkan maslah), (2) afektif, berhubungan dengan sikap, nilai-nilai dan apresiasi, dan (3) psikomotor, yakni berkaitan dengan kemampuan keterampilan seseorang (Loeloek Endah Poerwati dan Sofan Amri, 013: 47-48). Oleh karena itu pada tujuan pembelajaran IPS pada Kurikulum 2013 dimaksudkan agar kegiatan Pembelajaran IPS diselenggarakan secara interaktif, inspiratif, menyenangkan, menantang, memotivasi peserta didik untuk berpartisipasi aktif, serta memberikan ruang yang cukup bagi prakarsa, kreativitas, dan kemandirian sesuai dengan bakat, minat, dan perkembangan fisik serta psikologis peserta didik.

Ruang lingkup materi IPS meliputi perilaku sosial, ekonomi dan budaya manusia dimasyarakat. Masyarakat merupakan sumber utama IPS. Aspek kehidupan sosial terkait dengan ruang tempat tinggalnya apapun yang di pelajari, apakah itu hubungan sosial, ekonomi, budaya, kejiwaan, sejarah, geografis ataukah politik, sumbernya adalah masyarakat. Menurut Winata putra (dalam Iwan Setiawan, dkk, 2017: 78), visipendidikanIPSadalahsebagai program pendidikan yang menitikberatkan pada pengembangan individu peserta dididik sebagai "aktor sosial" yang mampu mengambil keputusan yang bernalar dan sebagai "warganegara" yang cerdas, memiliki komitmen, bertanggung jawab dan partisipatif. Melalui pendidikan IPS, peserta didik dibina dan di kembangkan kemampuan mental serta intelektualnya menjadi warga negara yang memiliki

202 | Seminar Nasional Sejarah ke 4 Jurusan Pendidikan Sejarah Universitas Negeri Padang 
keterampilan dan kepedulian sosial serta bertanggung jawab terhadap pembangunan nasional dengan memanfaatkan potensi sumber daya yang ada secara optimal dan lestari.

Misi dari pendidikan IPS adalah bukan untuk menjejali siswa dengan sejumlah materi yang bersifat hafalan belaka, melainkan terletak pada upaya agar mereka mampu menjadikan apa yang telah dipelajari sebagai bekal dalam memahami dan ikut serta dalam melakoni kehidupan di lingkungan masyarakat, serta sebagai bekal bagi dirinya untuk melanjutkan pada pendidikan yang lebih tinggi (Solihatin dan Raharjo, 2007: 15).

Mengacu pada visi dan misi pendidikan IPS sehingga Materi IPS SMP sangat bervariasi dan menuntut keahlian dari setiap pengajar sedangkan kemampuan guru dalam pengelolaan pembelajaran IPS masih kurang dari keprofesionalannya. Kekurangmampuan guru pengajar IPS adalah dalam hal penguasaan kedalaman materi ajar IPS itu sendiri. Hal tersebut disebabkan para guru IPS SMP berasal dari satu disiplin ilmu sosial sehingga menyulitkan guru tersebut untuk dapat langsung menguasai materi ajar IPS terpadu (Ekonomi, Sejarah, Geografi, dan Sosiologi).

\section{Pembelajaran Kooperatif}

Pembelajaran kooperatif adalah model pemeblajaran yang menuntut guru untuk aktif karena guru diharuskan menetapkan tugas-tugas, pertanyaan-pertanyaan, dan menyediakan bahan-bahan serta informasi yang dirancang untuk membantu siswa menyelesaikan permasalahan sesuai dengan materi yang diajarkan. menurut Agus Suprijono (2010: 58), pembelajaran kooperatif memiliki ciri: 1) Memudahkan siswa belajar sesuatu yang bermanfaat, seperti: fakta, keterampilan, nilai, konsep, dan bagaimana hidup serasi dengan sesama; 2) Penegtahuan, nilai, dan aketerampilan yang diakui oleh mereka dan yang kompeten untuk menilai.

\section{Hasil Belajar}

Bagi siswa dan guru, hasil belajar sangat penting karena untuk dapat mengukur proses pembelajaran apakah sudah berjalan sesuai dengan rancangan yang telah disusun oleh guru. Denikian juga bagi siswa, untuk mengukur kemampuan siswa baik dari bidang kognitif dan afektif, maupun psikomotor. Untuk mengukur kemampuan siswa, guru akan melakukannya dengan sistem penilaian. Prinsip yang mendasari penilaian hasil belajar yaitu untuk memberi harapan bagi siswa dan guru untuk dapat meningkatkan kualitas pembelajaran. Kualitas dalam arti siswa menjadi pembelajar yang efektif dan guru menjadi 203 | Seminar Nasional Sejarah ke 4 Jurusan Pendidikan Sejarah Universitas Negeri Padang 
motivator yang baik. Dalam kaitan itu, guru dan pembelajar dapat menjadikan informasi hasil penilaian sebagai dasar dalam menentukan langkah-langkah pemecahan masalah, sehingga mereka dapat memperbaiki dan meningkatkan belajarnya (Rasyid, 2008: 67).Menurut Sudjana(2005:44, 68), jenis penilaian untuk mengukur hasil belajar siswa dapat berupa: (1) tes uraian atau tes esai dan tes objektif, dan (2) teknik nontes berupa kuesioner atau wawancara, skala (skala penilaian, skala sikap, skala minat), observasi atau pengamatan, studi kasus dan sosiometri. Pada penelitian ini, tes yang digunakan berupa tes tertulis dan hasil dari diskusi kelompok yang telah dipaparkan oleh amsing-masing kelompok.

\section{Metode Literasi}

Dalam kamus online Merriam-Webster, literasi berasal dari istilah Latin 'literature" dan dan dalam Bahasa Inggris letter yang berarti huruf. Literasi merupakan kemampuan melek huruf atau aksara yang didalamnya meliputi kemampuan membaca dan menulis. Namun, makna literasi juga mencakup melek visual maksudnya adalah kemampuan untuk mengenali dan memahami ide-ide yang disampaikan secara visual (adegan, video, gambar). Dengan demikian, literasi adalah suatu kemampuan individu dalam mengolah dan memahami informasi ketika melakukan kegiatan membaca dan menulis. Tujuan literasi adalah untuk mengoptimalkan kemampuan seseorang dalam membaca, menulis, dan berkomunikasi.

\section{Metode Penelitian}

Penelitian ini termasuk jenis Penelitian dekripsi yang dilakukan oleh peneliti pada bulan Maret 2019. Dalam penelitian ini, peneliti sebagai guru yang mengajar di kelas, mahasiswa dan guru kelas bertugas sebagai pengamat. Subjek penelitian adalah siswa kelas VII-B SMP Kristen Satya Wacana Salatiga Semester Genap Tahun Ajaran 2018/2019. Jumlah siswa kelas VII-B ada 22 siswa yang terdiri dari 12 siswa laki-laki dan 10 siswa perempuan. Variabel penelitiannya:(1)Variabel bebasnya adalah penerapan metode literasi, sedang 2) Variabel terikatnya adalah hasil belajar IPS materi teori-teori masuknya agama Hindu-Buddha di indonesia.

Teknik dan instrument pengumpulan data adalah dengan studi dokumen yang dimiliki guru kelas yakni nilai ulangan harian dan hasil diskusi kelompok pada Semester Genap tahun ajaran 2018/2019 pada mata pelajaran IPS. Observasi di kelas dilakukan untuk mengamati aktivitas 204 | Seminar Nasional Sejarah ke 4 Jurusan Pendidikan Sejarah Universitas Negeri Padang 
siswa dan proses pembelajaran. Bentuk tes yang digunakan dalam penelitian ini adalah tes tertulis dalam bentuk essay yang digunakan untuk mengukur pemahaman siswa pada ranah kognitif tentang pemahaman teori - teori masuknya agama Hindu-Buddha di Indonesia. Teknik untuk menganalisis data dalam penelitian ini yaitu analisis deskriptif yaitu mendeskripsikan proses pembelajaran dan hasil tes setelah menerapkan metode literasi. Melalui penerapan metode literasi diharapkan hasil belajar IPS siswa pada materi teori-teori masuknya agama HinduBuddha di Indonesia mencapai ketuntasan yakni 70.

\section{Hasil Dan Pembahasan}

Pada pelaksanaan pembelajaran, siswa dibagi menjadi 4 kelompok, 2 kelompok beranggotakan 5 orang siswa, dan 2 kelompok beranggotakan 6 orang siswa. Guru menampilkan mengenai teori-teori masuknya agama Hindu-Buddha di Indonesia dengan menggunakan gambar peta melalui media power point. Kemudian menjelaskan pendapaat para ahli tentang teori masuknya agama Hindu-Buddha di Indonesia. Dalam penjelasan ini siswa diajak berpikir kritis tentang bagaimana teori-teori itu muncul yang nantinya membawa pengaruh pada perkembangan agama Hindu-Buddha di Indonesia sampai saat sekarang ini.

Kemudian siswa dibimbing guru untuk menyimak teks bacaan pada Buku Siswa (BS). Siswa dibimbing guru menemukanpermasalahan berkaitan dnegan teori-teori masuknya agama Hindu-Buddha tersebut. Setelah itu setiap kelompok diminta mendiskusikan kembali teori-teori masuknya agama Hindu-Buddha di Indonesia dan memilih teori mana yang dipandang masuk akal dengan memberikan penjelasannya. Dalam diskusi ini, guru mengarahkan siswa untuk membagi tugas bersama pada anggota kelompoknya. Selain itu, guru berkeliling untuk membantu kesulitan siswa dalam menuangkan kesamaan pendapat pada tiap kelompok. siswa diminta membaca kembali teks bacaan dan menyimak dengan baik-baik teks tersebut. Setelah masing-masing kelompok menentukan pendapatnya, maka mereka selanjutnya mendiskusikan dan mendeskripsikannya yang dituangkan dalam lembar kerja yang sudah disediakan oleh guru.

Setelah hasil diskusi masing-masing kelompok siap untuk dipresentasikan, maka masingmasing kelompok mempresentasikan hasil diskusinya di depan kelas. Mereka menyampaikan pendapat masing-masing kelompokdan alasan memilih teori tersebut. Guru memberi tanggapan dan apresiasi karena siswa telah aktif bekerja sama dengan teman kelompoknya serta sudah belajar kritis. Setelah semua kelompok presentasi di depan kelas, guru bersama siswa 205 | Seminar Nasional Sejarah ke 4 Jurusan Pendidikan Sejarah Universitas Negeri Padang 
menyimpulkan hasil diskusi dari beberapa kelompok yang telah disampaikan melalui presentasi di depan kelas.Berdasarkanpengamatandalam proses pembelajaran, siswasenangberdiskusi, menuangkangagasan, berpikir kritis,mencatat, dan memaparkan hasil diskusi kelompoknya di depan kelas.

Setelah dilaksanakan pembelajaran dengan menerapkan model pembelajaran koperatif dengan metode literasi, dari 22 siswa yang mengikuti evaluasi pembelajaran semua siswa tuntas yangdicapai melebihi KKM yang ditetapkan sekolah yakni 70.Nilai tertinggi yang dicapai siswa adalah 100, dan nilai terendah yang dicapai siswa adalah 75 dengan nilai rata-rata kelas 95,5. Dengan demikian dapat disimpulkan bahwa pembelajaran dengan penerapan metode literasidapat nenanamkan pemahaman sebuah peristiwa sejarah mata pelajaran IPS pada siswa kelas VIIB SMP Kristen Satya Wacana Salatiga. Hal ini ditunjukkan pada hasil belajar semua siswa (22 siswa) tuntas.

\section{Simpulan}

Penerapan model pembelajaran kooperatif dengan metode literasi dapat menanamkan pemahaman sebuah peristiwa sejarah pada mata pelajaran IPS materi teori-teori masuknya agama Hindu-Buddha di Indonesia pada siswakelas VII-B SMP Kristen Satya Wacana Salatiga. Metode ini memungkinkan siswa benar-benar belajar berpikir kritis melalui teks bacaan yang dibacanya sehingga dapat dipaahami dengan baik, melatih kerjasama, menulis, dan memaparkannya di depan kelas.

Penerapan model pembelajaran kooperatif dengan metode literasi mata pelajaran IPS materi teori-teori masuknya agama Hindu-Buddha di Indonesia didapatkanhasilbelajar IPS pada siswakelas VII-B SMP Kristen Satya Wacana Salatiga Semester Genap tahun ajaran 2018/2019 semua siswa tuntas. Hal ini terbukti bahwa hasil belajar siswa yang keseluruhaannya berjumlah 22 orang siswa nilai tertinggi yang dicapai siswa adalah 100 dan nilai terendah yang dicapai siswa adalah 75 dengan nilai rata-rata kelas 95,5.

\section{DAFTAR PUSTAKA}

Iwan Setiawan, dkk. 2017. IlmuPengetahuanSosial SMP/MTs Kelas VII. Buku Guru. Cetakan ke4. Jakarta: Kementerian Pendidikan dan Kebudayaan 
Poerwati, Loeloek Endah dan Sofan Amri. Panduan Memahami Kurikulum 2013. Jakarta: PT. Prestasi Pustakaraya

Solihatin, Etin dan Raharjo. 2007. Cooperative Learning: Analisis Model Pembelajaran IPS. Jakarta: BumiAksara

Sudjana. Nana. 2005. Penilaian Hasil Proses BelajarMengajar. Bandung: PT RemajaRosdakarya.

Suprijono, Agus. 2010. Cooperative Learning: Teori dan Aplikasi PAIKEM. Yogyakarta: pustaka Pelajar.

Sunardi, Herman J. Waluyo, AstiniSuudi, Nugraheni EkoWardani. Suggestopedia Based Storytelling Teaching Model For Primary Students In Salatiga. 64.Volume 6, issue 1 Januari 2018. www.mojet.net 